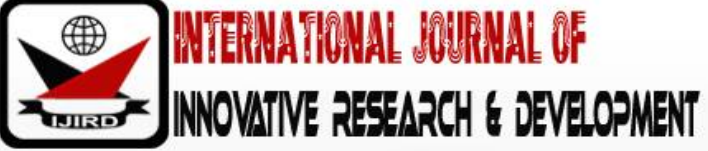

ISSN 2278 - 0211 (Online)

\section{Micro Influence on Earnings Management in the Basic and Chemical Industrial Sectors in Indonesia}

Said Djamaluddin
Postgraduate Lecturer, Mercu Buana University, Jakarta, Indonesia
Asteria Dian Perdanawati
Postgraduate Alumni, Mercu Buana University, Jakarta, Indonesia
Aty Herawati
Postgraduate Lecturer, Mercu Buana University, Jakarta, Indonesia

\begin{abstract}
:
This study aims to analyze the influence of Micro Factors (DER, Sales Growth, ROA, Firm Size) On Earning Management in the Basic Industry and Chemical sector in 2015-2017. The method of determining the sample of this study was purposive sampling. In accordance with predetermination criteria, obtained a sample of 29 companies with an observation period of 3 years so that number of samples was 87 companies. The analysis technique used is the Fixed Effect Models. The result Showed that DER, Sales Growth and ROA did not affect earnings Management. Only Firm Size has a significant positive affect on Earning management.
\end{abstract}

Keywords: Earnings management, DER, sales growth, ROA, firm size

\section{Introduction}

\subsection{Background}

Financial Reports are information media that are used to connect parties interested in the company. The importance of financial statements is also disclosed that financial statements are a means to account for what is done by managers over the resources of the owner. The performance parameters of a company that gets the main attention from investors and creditors from financial statements are profit and cash flow. When faced with two measures of financial accounting performance, investors and creditors must be sure that the performance measures that are the focus of their attention are measures of performance that can better describe the economic condition of the company and prospects for growth in the future. Therefore, in addition to the two measures of performance, investors and creditors also need to consider the financial characteristics of each company. At present earnings management is a common phenomenon that occurs in a number of companies. Earnings management is a manager's intervention in the financial reporting process with the aim of making a profit, both for managers and companies. The process of preparing financial statements can be done by leveling, increasing and decreasing profits.

The Basic and Chemical Industry Sector represents the elements used in everyday life. Almost all items of daily life products are products of Basic Industry and Chemical. In the coming years the potential for skyrocketing property in the coming year can drive the performance of cement stocks to rise again. In its implementation the Basic and Chemical Industry Sector is divided into 7 Industrial sub-sectors, namely: 1. Cement Industry Sub-sector, 2. Ceramic and Porcelain Industry Sub-Sector, 3. Metal Industry Sub-Sector, 4. Chemical Industry Subsector, 5. Animal Feed Industry Sub-sector , 6. Sub-sector of Plastic and Packaging Industry, 7. Pulp and paper sub-sectors. Many companies in basic and chemical industries have created a fierce competition between basic and chemical industry companies. The development of the company in the basic industrial and chemical industry sectors in Indonesia both in the number and size of the company will have implications for increasingly high competition among companies. Companies are required to maintain and even improve performance in order to survive in times of crisis and competition. The basic industrial sector and chemistry do Profit Management by reducing profits every year. This is done for political and taxation motivations so that managers can develop their companies by reducing tax costs and not being the center of attention that will lead to high political costs. Basic industrial and chemical sector companies conduct profit management by reducing profits and manipulating financial statements so that they can affect retained earnings. In this case, management suppresses retained earnings so that assets owned by the company increase and are able to develop and increase company value. Identification of problems in this study are as follows: There is a tendency for companies that have a low Debt Equity Ratio (DER) ratio to practice Profit Management. Companies with low sales growth rates also motivate management in conducting profit management. The effectiveness of the company in generating influential profits from sales growth. The current condition of company 
profitability can encourage management to do Profit Management to save its performance in the eyes of the owner. Large companies have a greater impetus to do earnings management compared to smaller companies because large companies are subject to inspection. A large company (Firm Size) has a goal to expand its business and increase company assets. So that this research can be carried out more directed and in accordance with the objectives, the authors limit the research including Debt Equity Ratio (DER), Sales Growth (Sales Growth), Return On Assets (ROA) and Company Size (Firm Size) as internal factors that influence Profit management. This research is also limited to the Basic and Chemical Industry Sector that is listed on the Indonesia Stock Exchange and is available in full and audited annual financial reports for 2015-2017. The purpose of this study is to find out whether there is a positive influence between the independent variables (DER, Sales Growth, ROA, Firm Size) on the dependent variable Profit Management in the Basic Industry and Chemical Sector in 2015-2017. There are differences in the results of previous studies between DER, Sales Growth, ROA and Firm Size on Earnings Management, as follows: DER has a significant positive effect according to Astari, et al (2017) and Pujilestari, et al (2013). DER has a significant negative effect according to Arthawan et al. (2018). And DER has no significant effect according to Gunawan, et al (2015), Pradipta, et al (2015) and Kusumaningtyas (2014). Sales Growth has a significant positive effect according to Astari, et al (2017). Sales Growth has a significant negative effect according to Puji Lestari et al. (2013). And Sales Growth has no significant effect according to Kusumaningtyas (2014). ROA has a significant positive effect according to Astari, et al (2017) and Perwitasari (2014). ROA has a significant negative effect according to Pujilestari, et al (2013). And ROA has no significant effect according to Kusumaningtyas (2014). Firm Size has a significant positive effect according to Astari, et al (2017) and Pujilestari, et al (2013). Firm Size has a significant negative effect according to Perwitasari (2014), Arthawan, et al (2018) and Kusumaningtyas (2014). And Firm Size has no significant effect according to Gunawan, et al (2015) and Pradipta, et al (2015).

\section{Theoritical Review}

\subsection{Agency Theory}

Agency theory discusses the existence of an agency relationship, where a certain part (principal) delegates work to another part (agent). According to Jensen and Meckling (1976) the agency relationship arises when the principal works with an agent, where the principal will provide facilities and delegate authority and decision-making policies to the agent.

\subsection{Information Asymmetry}

Information asymmetry arises when managers in a company know all the information in the company to the company's prospects that are not known to shareholders or stakeholders.

\subsection{Signal Theory}

Signal theory is based on the idea that managers who have good information about the company try to convey that information to investors so that the company's stock price increases. However, the existence of information asymmetry problems, making managers not only announce that information, because it is possible for managers of other companies to also announce the same thing so as to make outside investors less trustful (Sugiarto, 2009: 48).

\subsection{Pecking Order Theory}

Wardian to (2013) explained that the Pecking Order theory further suggested the use of internal funding sources as the company's main funding source. This theory bases itself on information asymmetry, a term that indicates that management has more information (about prospects, risks and company value).

\subsection{Positive Accounting Theory}

According to Watts and Zimmerman (in Sulistyanto, 2008: 44) formulating three positive accounting theory hypotheses (Positive Accounting Theory) which can be used as the basis of understanding in earnings management actions are: Bonus Plan Hypotesis, Debt Covenant Hypothesis, Political Cost Hypothesis.

\subsection{Earning Management}

Earnings management is a condition where management intervenes in the process of preparing financial statements for external parties so that it can flatten, increase and decrease profits (Schipper, 1989 in Astari 2017). Earnings management in this study was measured by proxy discretionary accruals (DA) using the Modified Jones model (Jones Modification).

The following is a common pattern used in earnings management according to (Scott 2009 in Savitri 2014) can be done in a way:

\subsubsection{Taking a Bath}

Taking a bath is a pattern of earnings management carried out by making the company's profits in the current period to be very extreme low (even loss) or very extreme high compared to profits in the previous period or after.

\subsubsection{Income Minimization}

Income minimization is a pattern of earnings management carried out by making profits in the current period financial statements lower than actual profits. 


\subsubsection{Income Maximization}

Maximizing profit (income maximization) is a pattern of earnings management carried out by making profits in the current period financial statements higher than actual profits

- Leverage - One of the Leverage Ratios used is Debt to Equity Ratio (DER), which is the ratio used to acces debt with equity. This ratio is sought by comparing all debt, including current debt with all equity. This ratio is used to measure a company's ability to pay all its obligations, both short and long term if the company is dissolved (liquidated).

- Sales Growth - Growth ratio is a ratio that describes the ability of a company to maintain its economic position amid its economy and business sector. One of the ratios analyzed is Sales Growth, calculated by comparing sales in the year after deducting sales in the previous period divided by sales in the previous year.

- Profitability - OA is one type of profitability ratio that shows the return (return) on the amount of assets used in the company. The ratio of net income after tax is divided by total assets, used to measure management's ability to obtain profits (profits) as a whole.

- Company Size Firm size (Firm Size) can be defined as an effort to assess the size or size of a company. Company size is obtained from the natural logarithm of the total value of the company's assets at the end of the year.

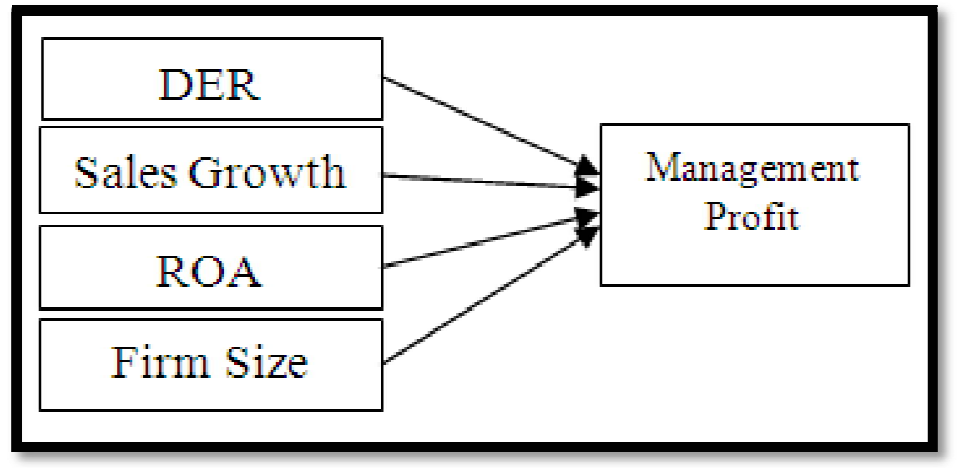

Figure 1: Thinking Framework

In this study, the hypothesis used is that there is the influence of independent variables, namely DER, Sales Growth, ROA and Firm Size on dependent variables, namely Profit Management. Based on the research problem formulation, the hypotheses put forward are as follows:

- DER has a positive effect on earnings management

- Sales Growth has a positive effect on earnings management

- ROA has a positive effect on earnings management

- Firm Size has a positive effect on earnings management

\section{Research Methods}

The method of determining the sample from this study is by purposive sampling in accordance with predetermined criteria and obtained a sample of 29 companies with a 3-year observation period so that the total sample of 69 companies. The data used in this study are secondary data in the form of financial statements of the Basic and Chemical Industry sectors listed on the Indonesia Stock Exchange in 2015-2017 which have been published on the website www.idx.co.id. The data obtained from the results of subsequent research were analyzed by panel data regression analysis using the help of the E views version 9.0 software program. The stages of data analysis are as follows: descriptive statistics, stationary data test, panel data regression method, panel data testing method, classical assumption testing (normality, autocorrelation, heteroscedasticity, multicollinearity), $\mathrm{F}$ test, determination coefficient (R2), $\mathrm{t}$ test.

\section{Analysis Results}

\subsection{Descriptive Statistics}

Presents minimum, maximum, and mean data for each variable. The Profit Management variable in 2015 has a minimum value of -0.183 and a maximum value of 0.096 . 2016 has a minimum value of -0.1510 and a maximum value of 0.151. 2017 has a minimum value of -0.0679 and a maximum value of 0.131 . The average of the Profit Management variable with the lowest value occurred in 2015 and 2017 at -0.0679 and the highest value occurred in 2016 at 0.1512 . he DER variable in 2015 has a minimum value of 0.0927 and a maximum value of 4.5469. 2016 has a minimum value of 0.1832 and a maximum value of 2.5597. 2017 has a minimum value of 0.1092 and a maximum value of 4.1897. The average of the DER variables during 2015-2017 is above 0.9 with the lowest value occurring in 2017 at 0.8527 and the highest value occurred in 2015 at 0.9499 . The Sales Growth variable in 2015 has a minimum value of -0.5430 and a maximum value of 0.5401. 2016 has a minimum value of -0.1713 and a maximum value of 0.5317 .2017 has a minimum value of -0.2368 and a maximum value of 0.168. The average of the Sales Growth variable during 2015-2017 is above 0.15 with the lowest value occurring in 2016 at -0.1713 and the highest value in 2017 at 1.0244 . he ROA variable in 2015 has a minimum value of -0.0605 and a maximum value of 0.1339 . 2016 has a minimum value of -0.0548 and a maximum value of 0.1577. 2017 has a minimum value of -0.0907 and a maximum value of 0.1411 . The average of the ROA variables during 
2015-2017 is above 0.22 with the lowest value occurring in 2017 of -0.0548 and the highest value in 2016 of 0.1577 . he Firm Size variable in 2015 has a minimum value of 0.1338 and a maximum value of 246849.2016 has a minimum value of 0.1366 and a maximum value of 24.2050. 2017 has a minimum value of 0.1612 and a maximum value of 24.5235. The average of Firm Size variables during 2015-2017 is above 27 Trillion with the lowest value occurring in 2016 which is 27.8663 Trillion and the highest in 2017 is 27.9985 Trillion.

\subsection{Stationary Data Test}

The results of the unit root test output are carried out at the level level of the earnings management variable, DER, Sales Growth, ROA and Firm Size indicate that the data is stationary. This result is seen from p value less than 0.05 and $\mathrm{ADF}$ value smaller than critical values $1 \%, 5 \%, 10 \%$.

\subsection{Panel Data Testing}

He chow test results show that the result of p-value of 0.0471 is smaller than 0.05 then $\mathrm{H} 0$ is rejected so that the right model is the Fixed Effect Model. And the results of the hausman test show that the result of p-value of 0.0419 is smaller than 0.05 then $\mathrm{H} 0$ is rejected so that the right model is the Fixed Effect Model. So the right Panel Data Regression Model Method in this study is the Fixed Effect Model method.

\subsection{Normality}

The Normality Test results shown in the Probability of Jarque-Bera are 0.035613 smaller than $\alpha 0.05$. This means that the residual is not normally distributed.

\subsection{Multicollinearity}

The Multicollinearity Test results concluded that there were no symptoms of multicollinearity between independent variables, because each independent variable had a VIF value $<10$.

\subsection{Heteroscedasticity}

Heteroscedasticity test results are known not to occur heteroscedasticity symptoms in the research data because the probability value of Obs $*$ R-squared is greater than the value of $\alpha$ or $0.5056>0.05$

\subsection{Autocorrelation}

The results of the Autocorrelation Test are shown in the Durbin Watson value of 1.997230, while the dL value is 1.1241 and the $\mathrm{dU}$ value is 1.7426 . The value of $\mathrm{dU}<\mathrm{dw}<4$ - $\mathrm{dU}$, so it can be concluded that the residual does not contain autocorrelation.

\subsubsection{Fixed Effect Model}

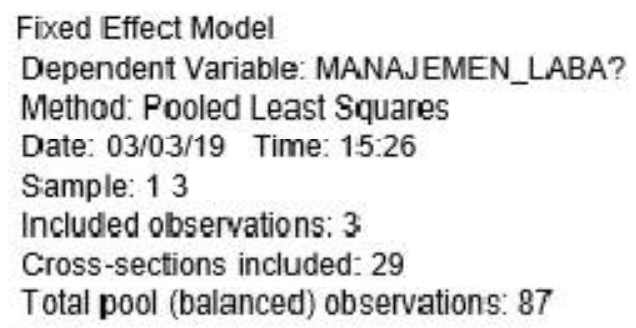

\begin{tabular}{crrrr}
\hline \hline Variable & Coefficient & Std. Error & t-Statistic & Prob. \\
\hline \hline C & -3.667485 & 1.275526 & -2.875272 & 0.0058 \\
DER? & 0.010976 & 0.027961 & 0.392558 & 0.6962 \\
SG? & -0.041474 & 0.031775 & -1.305268 & 0.1973 \\
ROA? & 0.240457 & 0.295700 & 0.813178 & 0.4197 \\
SIZE? & 0.130751 & 0.045792 & 2.855322 & 0.0061
\end{tabular}

R-squared

Adjusted R-squared

S.E. af regression

Sum squared resid

Log likelihood

F-statistic

Prob(F-statistic)
0.403863 Mean dependent var

0.050597 S.D. dependent var

0.055402 Akaike info criterion

0.165746 Schwarz criterion

149.0018 Hannan-Quinn criter.

3.000572 Durbin-Watson stat

0.032599
0.002559

0.056859

$-2.666709$

$-1.731364$

$-2.290074$

3.372769

Table 1: Panel Data Regression Model 


\subsubsection{Coefficient of Determination $\left(\mathrm{R}^{2}\right)$}

R-square value $(\mathrm{R} 2)=0.403863$ which shows that $40 \%$ of the Profit Management variance can be explained by changes in the DER variable, Sales Growth, ROA and Firm Size. While the remaining $60 \%$ is explained by other factors outside the research model.

- Test F- Can be seen in table 1 with a probability level of $95 \%(\alpha=5 \%)$ then the value of $p$-value $=0.032599<0.05$ and the value of $\mathrm{F}$ count 3.000572 $>\mathrm{F}$ table $(=2.78)$ so that $\mathrm{H} 0$ is rejected which means the independent variable has a significant relationship with the dependent variable.

- $\quad \mathrm{T}$ test - By using the Fixed Effect model, a panel data regression equation model is formed which can be formulated as follows:

$\mathrm{Y}=3.667485+0.010976 \mathrm{DER}-0.041374 \mathrm{SG}(-2.875272) \quad(0.392558)(-1.305268)+0.240457 \mathrm{RO}+0.130751 \mathrm{SIZE}$ (0.813178) (2.855322)

Numbers in parentheses are t-statistics.

Table 1 above is the output of Fixed Effect Model, with the basis of decision making: 1 . If the value of $t$-statistic or $t$ count $\varangle$ table (1.71088), then H0 is accepted, 2 . If the value of $t$-statistic or $t$ count $>t$ table ( 1.71088) or (for left direction) $t$ statistical value or $\mathrm{t}$ count <-t table (-1.71088), then $\mathrm{H} 0$ is rejected. The relationship between independent variables on earnings management as determined in table 1 shows the DER variable, Sales Growth and ROA does not have a significant effect on Earnings Management and other variables Firm Size has a significant effect on Earnings Management.

\section{Conclusions}

\subsection{Results}

\subsubsection{Effect of DER on-Profit Management}

This is not in accordance with the hypothesis statement made previously. A high DER level does not motivate Managers to do Profit Management by increasing profits. DER is a ratio that compares the amount of debt to equity. This ratio is often used by analysts and investors to see how much the company's debt is compared to the equity held by the company or shareholders.

\subsubsection{Effect of Sales Growth on Profit Management}

This is not in accordance with the hypothesis statement made previously. Sales growth shows the extent to which a company can increase sales compared to total sales overall. Sales growth also reflects the manifestation of investment success in the past period and can be used as a predictor of future growth. These results identify that companies whose sales go up or down do not affect the implementation of a company's earnings management.

\subsubsection{Effect of ROA on Profit Management}

This is not in accordance with the hypothesis statement made previously. Profitability shows management's ability to generate profits by utilizing assets used in operations. High and low profitability does not affect earnings management. The higher the profitability of the company, the company will tend not to do Profit Management because the company will be increasingly in the public spotlight.

\subsubsection{Effect of Firm Size on Profit Management}

This is in accordance with the hypothesis statement made previously. The larger the size of the company, the more information available to investors in making decisions related to investment in the company more and more. Larger companies also have a greater incentive to do earnings management compared to smaller companies because larger companies are subject to inspection.

\section{Recommendation}

Based on the results of the analysis and discussion, it is further concluded as follows:

- The independent variable DER has no effect on the dependent variable of Earnings Management in the Basic Industry and Chemical Sector in 2015-2017.

- Independent variable Sales Growth does not affect the dependent variable Profit Management in the Basic Industry and Chemical Sector in 2015-2017.

- Independent variable ROA does not affect the dependent variable Profit Management in the Basic Industry and Chemical Sector in 2015-2017.

- The independent variable Firm Size has a significant positive effect on the dependent variable Profit Management in the Basic and Chemical Industry sectors.

- Based on the results of the discussion and conclusions regarding the variables which include DER, Sales Growth, ROA and Firm Size on Profit Management in the Consumer Goods Industry Sector in 2015-2017, the author tries to convey some suggestions as considerations including the following:

\subsection{For Company}

Management so that in practicing earnings management is still within reasonable limits or still within the scope of generally accepted accounting methods and procedures so as not to mislead financial report users. 


\subsection{For prospective}

Investors It is recommended to invest in capital to be more selective in choosing a company. And better understand financial statements.

\subsection{For Shareholders}

It is suggested that information be as accurate as possible in the financial statements in order to make strategic and effective decisions for the company.

\subsection{For Creditors}

It is recommended in giving credit loans to pay more attention to financial statements, especially variables that are often the object of profit management.

\subsection{For Companies in Indonesia}

It is recommended to pay more attention to the effects of long-term earnings management which can lead to bankruptcy of the company itself and damage the Macroeconomic order.

\subsection{For Academics}

Further research is needed regarding other variables that affect earnings management, as well as the importance of Good Corporate Governance variables for further research.

\section{References}

i. Amertha, Indra Satya Prasavita., Ulupui, I Gusti Ketut Agung., Asri, I Gusti Ayu Made., dan Putri, Dwija. (2014). "Analysis Of Firm Size, Leverage, Corporate Governance On Earnings Management Practices (Indonesian Evidence)". Journal of Economics, Business, and Accountancy Ventura. Vol. 17, No. 2, August 2014, pages 259 268.

ii. Andayani, Tutut Dwi. (2010). "Pengaruh Karakteristik Dewan Komisaris Independent Terhadap Manajemen Laba". Tesis. Program Studi Magister Sains Akuntansi, Program Pascasarjana Universitas Diponegoro.

iii. Astari, Anak Agung Mas Ratih dan Suryanawa, I Ketut. (2017). "Faktor-Faktor Yang Mempengaruhi Manajemen ". E-Jurnal Akuntansi Universitas Udayana. Vol.20.1.Juli (2017): 290-319.

iv. Aygun, Mehmet., Ic, Suleyman., dan Sayim, Mustafa. (2014). "The Effects of Corporate Ownership Structure and Board Size on Earnings Management: Evidence from Turkey". International Journal of Business and Management. Vol. 9, No. 12; 2014.

v. Basuki, Tri A. (2016). "Analisis regresi dalam penelitian ekonomi \& bisnis: dilengkapi aplikasi SPSS \& Eviews". Jakarta: Rajawali Pers.

vi. Dwikusumowati, Meriam Zalzabilani dan Rahardjo, Shiddiq Nur. (2013). "Pengaruh Karakteristik Komite Audit Dan Karakteristik Perusahan Terhadap Manajemen Laba”. Diponegoro Journal Of Accounting. Volume 2 , Nomor 4, Tahun 2013, Halaman 1.

vii. Fathihani. (2016). "Pengaruh Struktur Modal, Pertumbuhan Perusahaan, Profitabilitas dan Ukuran Perusahaan Terhadap Manajemen Laba”. Tesis. Program Studi Magister Manajemen, Program Pascasarjana Universitas Mercubuana.

viii. Gonza'lez, Jesus Sa'enz dan Garcı'a-Meca, Emma. (2014). “Does Corporate Governance Influence Earnings Managementin Latin American Markets?".J Bus Ethics. (2014) 121:419-440.

ix. Gunawan, I Ketut., Darmawan, Nyoman Ari Surya., dan Purnamawati, I Gusti Ayu. (2015). "Pengaruh Ukuran Perusahaan, Profitabilitas Dan Leverage Terhadap Manajemen Laba Pada Perusahaan Manufaktur Yang Terdaftar Di Bursa Efek Indonesia (BEI)". e-Journal S1 Ak Universitas Pendidikan Ganesha. Jurusan Akuntansi Program S1 (Volume 03, No.01 Tahun 2015).

x. Hanafi, Mahmud M. (2015). Manajemen Keuangan. Cetakan ke lima. BPFE. Yogyakarta.

xi. Indracahya, Erik. (2017). "Pengaruh Elemen Good Corporate Governance, Leveraga, Umur Perusahaan, Ukuran Perusahaan dan Profitabilitas Terhadap Manajemen Laba". Tesis. Program Studi Magister Akuntansi, Program Pascasarjana Universitas Mercubuana.

xii. Kasmir . (2010). Pengantar Manajemen Keuangan. Kencana. Jakarta.

xiii. Kusumaningtyas, Metta. (2014). "Pengaruh Ukuran Komite Audit Dan Kepemilikan Institusional Dan Terhadap Manajemen Laba". Prestasi. ISSN 1411 - 1497 VOL. 13 NO. 1 - JUNI 2014.

xiv. Perwitasari, Dian. (2014). "Struktur Kepemilikan, Karakteristik Perusahaan Dan Manajemen Laba". Jurnal Akuntansi Multiparadigma JAMAL. Volume 5 Nomor 3 Halaman 345-510.

xv. Pradipta, Reza Hanung dan Hadiprajitno, P. Basuki. (2015). "Pengaruh Corporate Social Responsibility Dalam Perspektif Lingkungan Terhadap Manajemen Laba". Diponegoro Journal Of Accounting. Volume 4, Nomor 4, Tahun 2015, Halaman 1-12.

xvi. Pujilestari, Reisha dan Herusetya, Antonius. (2013). "Pengaruh Kualitas Audit Terhadap Manajemen Laba Transaksi Real - Pengakuan Pendapatan Strategis". Jurnal Akuntansi dan Keuangan Vol. 15, No. 2, November 2013, 75-85. 
xvii. Saputra, Taufik Aris. (2016). “Analisis Faktor-Faktor Yang Berpengaruh Terhadap Manajemen Laba Pada Perusahaan Manufaktur Bidang Consumer Goods Yang Terdaftar Di Bursa Efek Indonesia". Jurnal Manajemen \& Kewirausahaan. Volume 1 No.01 | Mei 2016.

xviii. Savitri, Enni. (2014). “Analisis Pengaruh Leverage Dan Siklus Hidup Terhadap Manajemen Laba Pada Perusahaan Real Estate Dan Property Yang Terdafar Di Bursa Efek Indonesia”. Jurnal Akuntansi. Vol. 3, No. 1, Oktober 2014: $72-89$.

xix. Sugiarto. (2009). Struktur Modal, Struktur Kepemilikan Perusahaan, Permasalahan Keagenan dan Informasi Asimetri. Graha Ilmu. Yogyakarta.

xx. Sugiyono. (2010). Metode Penelitian Pendidikan Pendekatan Kuantitatif, Kualitatif, dan R\&D. Alfabeta. Bandung.

xxi. Yamaditya, Vanian dan Raharja. (2014). "Pengaruh Asimetri Infomasi, leverage Dan Ukuran Perusahaan Terhadap Praktik Manajemen Laba". Diponegoro Journal Of Accounting. Volume 3 Nomor 4, Tahun 2014, Halaman 1.

xxii. Wiyadi., Trisnawati, Rina., Sasongko., Noer., dan Fauzi, Ichwani. (2015). "The Effect of Information symmetry, Firm Size, Leverage, Profitability and Employee Stock Ownership on Earnings Management with Accrual Model".International Journal of Business, Economics and Law. Vol. 8, Issue 2 (D 